\title{
YOGURT TINGGI ANTIOKSIDAN DAN RENDAH GULA DARI SARI BUAH APEL ROME BEAUTY DAN MADU
}

Antioxidant and Low Sugar Yogurt produce from Rome Beauty

Apples Extract and Honey

\author{
Nita Maria Rosiana'), Titik Khoiriyah ${ }^{1)}$ \\ 1) Program Studi Gizi Klinik, Politeknik Negeri Jember, Jl. Mastrip PO BOX 164, Jember, Jawa Timur, \\ Indonesia 68101 \\ nita.maria.r@polije.ac.id
}

Diterima 30 Agustus 2018; diterima pasca revisi 24 Oktober 2018

Layak diterbitkan 30 Oktober 2018

\begin{abstract}
Diabetes mellitus occurs due to metabolic disorders, especially high blood sugar levels. One way to treat type 2 diabetes mellitus is by diet modification and blood sugar control. This research aims to examine the extract of Rome Beauty apples and honey on yogurt as an food for type 2 diabetes mellitus. The method was used experimental design used Randomized Block Design with two factors. Factor $A$ is variation of apples extract with 3 levels ie $A 1=$ $10 \%$; $A 2=15 \%$; and $A 3=20 \% . B$ factor is honey variation with 2 levels ie $B 1=2.5 \%$; and $B 2=5 \%$. There are 6 total samples with 4 replications. The result showed that apples extract and honey gave higher antioxidant activity and total sugar. That it was also affects on organoleptic of yogurt. The best treatment was A3B2 (20\% apples extract dan 5\% honey with $32.83 \%$ antioxidant activity, $4.69 \%$ total sugar and panelist rather like this yogurt.
\end{abstract}

Keywords : Diabetes mellitus; honey; rome beauty apple; yogurt

\begin{abstract}
ABSTRAK
Diabetes mellitus adalah suatu gangguan metabolisme, terutama kadar gula darah yang tinggi. Salah satu cara untuk menangani pasien dengan diabetes mellitus tipe 2 dengan modifikasi pola makan dan kontrol gula darah. Penelitian ini bertujuan untuk menguji ekstrak apel dan madu pada yogurt sebagai snack untuk pasien dengan diabetes mellitus tipe 2. Desain penelitian yang digunakan adalah Rancangan Acak Kelompok dengan dua faktor. Salah satu faktornya adalah variasi ekstrak apel dengan 3 tingkatan yaitu A1 =10\%; A2 = $15 \%$; dan $A 3=20 \%$. Faktor $B$ adalah variasi madu dengan 2 level yaitu B1 = 2,5\%; dan B2 $=5 \%$. Ada 6 total sampel dengan 4 ulangan. Hasilnya menunjukkan bahwa semakin tinggi penambahan ekstrak apel dan madu maka semakin tinggi aktivitas antioksidan dan total gula. Perlakuan terbaik adalah A3B2 (20\% ekstrak apel dan 5\% madu dengan aktivitas antioksidan 32,83\%, 4,69\% gula total dan panelis agak menyukai yogurt ini.
\end{abstract}

Kata Kunci : Diabetes mellitus; madu; ekstrak apel rome beauty; yogurt 


\section{PENDAHULUAN}

Prevalensi penderita diabetes melitus pada tahun 2013 di Indonesia (2,1\%) mengalami peningkatan dibandingkan pada tahun $2007(1,1 \%)$, sedangkan untuk penderita diabetes melitus tipe 2 sendiri pada Provinsi Jawa Timur (2,5\%) prevalensinya lebih tinggi dari prevalensi nasional $(2,1 \%)$ (Kementerian Kesehatan Republik Indonesia, 2013). Menurut data Dinas Kesehatan Kabupaten Jember terdapat 5.278 kasus baru pasien diabetes melitus dan 15 diantaranya meninggal dunia (Dinas Kesehatan Kabupaten Jember, 2016). Upaya penanganan pasien penderita diabetes melitus tipe 2 adalah dengan cara merubah pola makan yakni memberikan alternatif makanan selingan seperti yogurt. Yogurt dengan aktivitas antioksidan yang tinggi dapat meredam stress oksidatif (Lingga, 2012) sehingga dapat mencegah terjadi komplikasi. Selain itu bakteri probiotik pada yogurt seperti Lactobacillus achidophillus dan Bifidobacterium lactis dapat meningkatkan status antioksidan pada penderita diabetes melitus tipe 2 (Ejtahed et al., 2012). Status antioksidan yang tinggi diharapkan dapat mencegah terjadi komplikasi penyakit pada penderita diabetes mellitus. Antioksidan dapat menghambat tahap awal retinopati, nefropati, dan neuropati. Selain itu, antioksidan dapat menghambat komplikasi mikrovaskular, penurunan insidens penyakit jantung koroner, perbaikan sistem saraf otonom jantung, dan perbaikan vasodilatasi (Setiawan \& Suhartono, 2005).

Meskipun yogurt pada dasarnya telah mengandung antioksidan yang berasal dari hidrolisis protein menjadi peptida bioaktif, namun diperlukan bahan pangan lain yang dapat ditambahkan pada yogurt guna meningkatkan antioksidan, yaitu apel rome beauty. Pemberian jus apel hijau (rome beauty) kepada hewan coba sebanyak 7,602 $\mathrm{g} / 200 \mathrm{~g}$ BB setelah diberi induksi deksametason secara oral dengan dosis 0,6 $\mathrm{mg} / 200 \mathrm{~g} \mathrm{BB}$ tikus dapat menurunkan ratarata kadar gula dari $288,71 \pm 9,52 \mathrm{mg} / \mathrm{dL}$ menjadi $108,71 \pm 5,65 \mathrm{mg} / \mathrm{dL}$ dalam waktu 7 hari (Khotimah, 2016). Selain itu, pada penelitian yang dilakukan oleh Aini (2010) pemberian jus buah apel hijau (rome beauty) dan seledri juga berpengaruh terhadap penurunan kadar gula darah sebesar 118,05 mg/dL (31,50\%). Buah apel mengandung flavonoid terutama senyawa quercitin (golongan flavonol) yang merupakan sumber antioksidan.

Quercitin bermanfaat sebagai antioksidan kuat yang mampu mencegah terjadinya kerusakan DNA dan komponen penting dalam tubuh akibat dari radikal bebas (Dalimartha, 2013)

Selain memperhatikan asupan antioksidan, asupan gula darah merupakan hal utama yang perlu dikendalikan dalam pelaksanaan diet diabetes melitus. Yogurt pada umumnya menggunakan pasir sebagai pemberi rasa manis. Gula ini dapat digantikan dengan madu. Madu mempunyai rasa manis yang berbeda dengan gula atau pemanis lainnya. Rasa manis tersebut berasal dari cairan manis (nectar) yang terkandung pada ketiak daun maupun bunga yang dihisap lebah.

Madu mempunyai kandungan fruktosa $(38,19 \%)$ dan glukosa $(31 \%)$. Sisanya terbentuk dari disakarida (maltose, isomaltosa, dan sukrosa), trisakarida dan oligosakarida. Madu juga mengandung sejumlah senyawa yang memiliki aktivitas antioksidan, yaitu pinobanksin, pinocembrin, chrysin, katalase, dan vitamin C (Subakti, 2012).
*Corresponding author :

Nita Maria Rosiana

Email : nita.maria.r@polije.ac.id

Program Studi Gizi Klinik, Politeknik Negeri Jember, Jl. Mastrip PO BOX 164, Jember, Jawa Timur, Indonesia 68101
How to cite :

Rosiana, N.M., \& Khoiriyah, T. (2018). Yogurt Tinggi Antioksidan dan Rendah Gula dari Sari Buah Apel Rome Beauty dan Madu. Jurnal Ilmu dan Teknologi Hasil Ternak, 13 (2), 81-90 
Meskipun madu memiliki gula sederhana seperti fruktosa dan glukosa namun masih aman bagi penderita diabetes. Bakteri probiotik pada yogurt akan menggunakan gula sederhana pada madu sebagai sumber energi selama proses fermentasi. Yoghurt ini mengandung aktivitas antioksidan tinggi dengan kadar gula yang rendah. Oleh sebab itu, penelitian ini diharapkan dapat berkontribusi dalam mengembangkan produk pangan fungsional tinggi antioksidan dan rendah gula sebagai alternatif makanan selingan pada diet diabetes melitus tipe 2 .

\section{MATERI DAN METODE}

Bahan pembuatan yogurt adalah buah apel rome beauty diperoleh dari petani apel di Dusun Nongkojajar Desa Wonosari Kecamatan Tutur Kabupaten Pasuruan, susu sapi segar dari peternak sapi perah di Desa Kemuning Lor Kecamatan Arjasa Kabupaten Jember, madu dari penjual madu asli di Desa Jeblog Kecamatan Talun Kabupaten Blitar, bakteri yang digunakan adalah Streptococcus thermopillus dan Lactobacillus bulgaricus yang diperoleh dari Laboratorium Mikrobiologi Jurusan Teknologi Hasil Pertanian Fakultas Teknologi Pertanian Universitas Jember. serta bakteri Lactobacillus acidophilus yang diperoleh dari Laboratorium Mikrobiologi Jurusan Biologi Fakultas Matematika dan Ilmu Pengetahuan Alam Universitas Jember.

Alat yang digunakan untuk pembuatan yogurt meliputi baskom, panci stainless steel, telenan, sendok stainless steel, kompor gas, tabung gas (elpiji), pisau, juicer, incubator, termometer, gelas plastik beserta tutupnya.

\section{Metode Penelitian yang Digunakan}

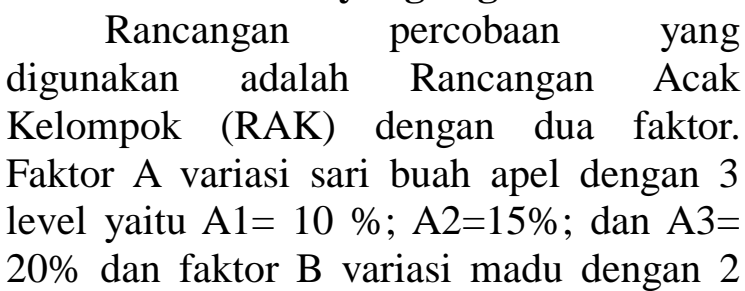

level yaitu $\mathrm{B} 1=2,5 \%$; dan B2=5\%. Jumlah sampel ada 6 dengan 4 kali ulangan sehingga didapatkan 24 sampel percobaan.

\section{Pembuatan Sari Buah Apel}

Pembuatan sari buah apel dimulai dari pencucian apel segar menggunakan air yang mengalir, kemudian buah apel dipotong menjadi dua bagian, lalu di hilangkan bijinya, selanjutnya di potong kembali menjadi ukuran $3 \times 3 \mathrm{~cm}$, kemudian di blanching pada suhu $\pm 82-100^{\circ} \mathrm{C}$ dengan menggunakan pengukusan selama 5 menit untuk mencegah terjadinya browning, lalu didinginkan hingga mencapai suhu ruang \pm $20-30^{\circ} \mathrm{C}$, setelah itu potongan buah apel dihancurkan menggunakan juicer hingga terpisah ampas dan sarinya, setelah potongan buah apel selesai dijuicer, sari buah apel siap dipakai (Modifikasi Kinanthi, 2016).

\section{Pembuatan Starter Yoghurt}

Pembuatan starter yoghurt dimulai dengan menimbang susu skim bubuk sebanyak 5 gram, kemudian larutkan ke dalam $100 \mathrm{~mL}$ air matang, lalu ambil $10 \mathrm{~mL}$ dari larutan tersebut dan dipasteu risasi pada suhu $90^{\circ} \mathrm{C}$ selama 10 menit, setelah itu dinginkan hingga mencapai suhu $45^{\circ} \mathrm{C}$, kemudian lakukan inokulasi kultur starter tunggal Lactobacillus bulgaricus, Streptococcus thermophilus, dan Lactobacillus acidophilus sebanyak $1 \mathrm{~mL}$ dengan perbandingan $1: 1: 1$, lalu diinkubasi pada suhu $30-37^{\circ} \mathrm{C}$ selama 24 jam.

\section{Pembuatan Yoghurt}

Prosedur pembuatan yoghurt dilakukan dengan mencampurkan madu sesuai perlakuan ke dalam $250 \mathrm{~mL}$ susu sapi, lalu homogenisasi, setelah itu lakukan pasteurisasi pada suhu $90^{\circ} \mathrm{C}$ selama 10 menit, kemudian campuran susu dan madu tersebut didinginkan hingga mencapai suhu $\quad 45^{\circ} \mathrm{C}$, selanjutnya tambahkan starter yoghurt sebanyak 5\% dari volume susu sapi, lalu homogenisasi, kemudian tambahkan sari buah apel rome beauty sesuai perlakuan, lalu homogenisasi, 
setelah itu lakukan inkubasi pada suhu ruang selama 24 jam (modifikasi dari Rosiana \& Amareta, 2016).

\section{Pengamatan}

Parameter pengamatan yaitu aktivitas antioksidan (Butsat \& Siriamornpun, 2016), gula total, uji organoleptik, kadar air, kadar abu, $\mathrm{pH}$, total bakteri asam laktat, total asam tertitrasi. Penilaian terhadap uji hedonik adalah (5) sangat suka, (4) suka, (3) agak suka, (2) tidak suka, (1) sangat tidak suka. Sedangkan penilaian pada uji mutu hedonic seperti yang disajikan pada Tabel 1. Semua data diuji statistic menggunakan SPSS v16.0.

Tabel 1. Penilaian Uji Mutu Hedonik

\begin{tabular}{ccc}
\hline Organoleptik & Kriteria & Skor \\
\hline \multirow{3}{*}{ Rasa } & Sangat asam & 5 \\
& Asam & 4 \\
& Agak asam & 3 \\
& Hambar & 2 \\
& Sangat hambar & 1 \\
\hline \multirow{3}{*}{ Warna } & Coklat & 5 \\
& Coklat kekuningan & 4 \\
& Kuning & 3 \\
& Putih kekuningan & 2 \\
& Putih & 1 \\
\hline \multirow{3}{*}{ Aroma } & Aroma khas apel sangat kuat & 5 \\
& Aroma khas apel kuat & 4 \\
& Aroma khas apel agak kuat & 3 \\
& Aroma khas yogurt kuat & 2 \\
& Aroma khas yogurt sangat & 1 \\
& kuat & 5 \\
& Sangat kental & 4 \\
& Kental & 3 \\
& Sedang & 2 \\
& Cair & 1 \\
\hline
\end{tabular}

\section{HASIL DAN PEMBAHASAN}

\section{Aktivitas Antioksidan}

Antioksidan adalah suatu senyawa yang mampu menggangu reaksi rantai radikal bebas seperti halnya dalam reaksi oksidasi lipida. Data pada Tabel 2 menunjukkan hasil analisis aktivitas antioksidan yoghurt pada berbagai perlakuan didapatkan hasil rata- rata sebesar 27,10\% sampai 32,83\%. Kadar aktivitas antioksidan tertinggi $(32,83 \%)$ terdapat pada perlakuan A3B2 (20\% sari buah apel dan 5\% madu). Sedangkan aktivitas antioksidan terendah $(27,10 \%)$ terdapat pada perlakuan A1B1 (10\% sari buah apel dan 2,5\% madu). Besarnya nilai aktivitas antioksidan dipengaruhi oleh variasi penambahan sari buah apel dan madu.

Penggunaan sari apel dan madu mampu meningkatkan aktivitas antioksidan pada yogurt. Hal ini sesuai dengan penelitian yang dilakukan oleh Uttuh (2016) yang membuktikan bahwa penambahan bahan makanan yang mengandung antioksidan alami seperti sari buah duwet dan madu dapat meningkatkan aktivitas antioksidan serta dapat memberikan manfaat bagi kesehatan tubuh dengan menyeimbangkan antara pertahanan antioksidan dan produksi radikal bebas. Mekanisme kerja antioksidan dalam menurunkan kadar gula darah yaitu 
antioksidan diduga berperan secara signifikan meningkatkan sensitivitas reseptor insulin dan mampu memperbaiki fungsi sel $\beta$ pankreas sehingga insulin yang berfungsi untuk mengontrol kadar gula darah dapat bekerja dengan optimal dan kadar gula darah menjadi turun (Lingga, 2012).

Hiperglikemia yang terjadi pada penderita diabetes melitus turut terlibat dalam pembentukan radikal bebas, dimana hiperglikemia tersebut menyebabkan terjadinya glikasi protein, autooksidasi glukosa, dan aktivasi jalur metabolism poliol yang sela jutnya mempercepat pembentukan Reactive Oxygen Spesies (ROS) di dalam mitokondria yang akan mengakibatkan disfungsi endotel dan berbagai kerusakan oksidatif berupa komplikasi diabetes (aterosklerosis, penyakit jantung, retinopati diabetik, nefropati diabetik, neuropati diabetik, dan katarak).

Mekanisme kerja antioksidan dalam mencegah terjadi komplikasi yaitu antioksidan diyakini dapat memperbaiki disfungsi endotel dengan cara mengekspresikan beberapa faktor yang berperan dalam perbaikan endotel melalui peningkatan mobilisasi EPC dari bone marrow.

Peningkatan mobilisasi EPC tersebut dapat memperbaiki jaringan dan vaskuler yang mengalami kerusakan sehingga dapat mencegah komplikasi vaskuler lebih lanjut (Peristiowati, 2016). Ejtahed et al (2012) menyebutkan bahwa konsumsi yogurt probiotik dapat meningkatkan status antioksidan pada penderita diabetes mellitus tipe 2 .

Yogurt tersebut mengandung Lactobacillus acidophilus La5 dan Bifidobacterium lactis Bb12. Yogurt probiotik mampu menurunkan kadar gula puasa dan hemoglobin A1c, meningkatkan eritrosit superoksida dismutase dan glutation peroksidase dan total status antioksidan. Selain itu juga menurunkan konsentrasi malonaldehid.

Bakteri probiotik mampu menurunkan stress oksidatif dengan menghambat oksidasi askorbat, mengikat ion logam, mengurangi aktivitas dan menangkap radikal anion superoksida, hydrogen peroksida dan radikal bebas serta menghambat oksidasi lipid. Salah satu hasil metabolit pada yogurt adalah peptida bioaktif yang memiliki sifat antioksidan.

Tabel 2. Aktivitas Antioksidan dan Kadar Gula Total pada Yoghurt

\begin{tabular}{cccc}
\hline Sari Buah Apel (\%) & Madu (\%) & $\begin{array}{c}\text { Aktivitas Antioksidan } \pm \\
\text { SD }(\%)\end{array}$ & $\begin{array}{c}\text { Kadar Gula Total SD } \\
(\%)\end{array}$ \\
\hline 10 & 2,5 & $27,10 \pm 0,07^{\mathrm{a}}$ & $2,53 \pm 0,04^{\mathrm{a}}$ \\
& 5 & $28,46 \pm 0,04^{\mathrm{b}}$ & $2,94 \pm 0,03^{\mathrm{b}}$ \\
\hline 15 & 2,5 & $29,57 \pm 0,05^{\mathrm{c}}$ & $3,39 \pm 0,04^{\mathrm{c}}$ \\
& 5 & $30,58 \pm 0,02^{\mathrm{d}}$ & $4,15 \pm 0,06^{\mathrm{d}}$ \\
\hline 20 & 2,5 & $31,72 \pm 0,05^{\mathrm{e}}$ & $4,46 \pm 0,05^{\mathrm{e}}$ \\
& 5 & $32,83 \pm 0,03^{\mathrm{f}}$ & $4,69 \pm 0,04^{\mathrm{f}}$ \\
\hline
\end{tabular}

Keterangan : Data merupakan rerata empat kali ulangan dan disajikan \pm SD

Notasi yang sama menunjukkan tidak beda nyata menurut uji Duncan $\alpha=0,05$ pada aktivitas antioksidan dan Mann Whitney $\alpha=0,05$ pada kadar gula total

\section{Kadar Gula Total}

Monosakarida dan digliserida seperti fruktosa, laktosa, glukosa, dan sukrosa tergolong sebagai gula yang terkadung dalam suatu bahan pangan. Data pada Tabel 2 yaitu hasil analisis kadar gula total yogurt pada berbagai perlakuan didapatkan hasil rata-rata sebesar $2,53 \%$ sampai $4,69 \%$. Kadar gula total tertinggi $(4,69 \%)$ terdapat pada perlakuan A3B2 (20\% sari buah apel rome beauty dan 5\% madu). Sedangkan kadar gula total terendah $(2,53 \%)$ terdapat pada perlakuan A1B1 (10\% sari buah apel rome beauty dan 2,5\% madu). Besarnya 
nilai kadar gula total dipengaruhi oleh variasi penambahan sari buah apel rome beauty dan madu, oleh karena itu kadar gula total memiliki nilai yang beragam pada setiap perlakuannya.

Selain kebutuhan antioksidan, pada penderita diabetes mellitus juga harus dibatasi asupan gula, yaitu 5\% saja. Penggunaan gula pada yogurt berfungsi sebagai sumber energi bagi mikroorganisme. Penggantian gula dengan madu karena pada madu selain mengandung gula juga terdapat antioksidan seperti yaitu pinobanksin, pinocembrin, chrysin, katalase, dan vitamin C (Subakti, 2012). Selain itu yogurt ini juga dapat diklaim sebagai pangan rendah gula. Menurut Peraturan Kepala Badan Pengawas Obat dan Makanan Republik Indonesia (2016), suatu produk makanan yang masuk dalam kategori rendah gula jika kandungan gula dalam makanan tersebut maksimal sebesar $5 \%$.
Penggunaan bahan pemanis seperti ekstrak daun stevia dan kayu manis dapat meningkatkan kadar gula total suatu produk makanan (Umami, 2015; Hastuti, 2014).

\section{Organoleptik}

Tabel 3 menunjukkan bahwa semakin tinggi penambahan sari buah apel dan madu maka warna menjadi semakin coklat kekuningan, rasa semakin asam, aroma menjadi khas apel, dan tekstur menjadi semakin cair.

Kesukaan warna berkisar antara 2,773,41 yaitu dari putih kekuningan hingga coklat kekuningan, rasa berkisar antara 2,77-3,64 yaitu dari agak asam hingga asam, skor aroma dari 3,13-3,26 yaitu dari aroma khas apel agak kuat hingga aroma khas apel kuat, tekstur berkisar antara 2,793,69 yaitu dari cair hingga kental. Secara keseluruhan semakin tinggi penambahan sari buah apel dan madu maka kesukaan akan semakin meningkat.

Tabel 3. Hasil Uji Organoleptik Yogurt

\begin{tabular}{|c|c|c|c|c|c|c|c|c|c|c|}
\hline \multirow{2}{*}{$\begin{array}{c}\text { Sari } \\
\text { Buah } \\
\text { Apel } \\
(\%)\end{array}$} & \multirow[b]{2}{*}{$\begin{array}{c}\text { Madu } \\
(\%)\end{array}$} & \multirow[b]{2}{*}{ Warna } & \multicolumn{2}{|c|}{ Mutu Hedonik } & \multicolumn{6}{|c|}{ Hedonik } \\
\hline & & & Rasa & Aroma & Tekstur & Warna & Rasa & Aroma & Tekstur & Overall \\
\hline \multirow[t]{2}{*}{10} & 2,5 & $2,15^{\mathrm{a}}$ & $3,87^{\mathrm{c}}$ & $3,08^{\mathrm{bc}}$ & $2,36^{\mathrm{bc}}$ & $2,15^{\mathrm{a}}$ & $3,87^{\mathrm{c}}$ & $3,08^{\mathrm{bc}}$ & $2,79^{\mathrm{ab}}$ & $2,79^{\mathrm{a}}$ \\
\hline & 5 & $2,13^{\mathrm{a}}$ & $3,51^{\mathrm{bc}}$ & $2,62^{\mathrm{ab}}$ & $2,56^{\mathrm{cd}}$ & $2,13^{\mathrm{a}}$ & $3,51^{\mathrm{bc}}$ & $2,62^{\mathrm{ab}}$ & $3,03^{b c}$ & $3,08^{\mathrm{ab}}$ \\
\hline \multirow[t]{2}{*}{15} & 2,5 & $3,64^{\mathrm{b}}$ & $3,38^{b}$ & $2,97^{b c}$ & $2,13^{\mathrm{ab}}$ & $3,64^{\mathrm{b}}$ & $3,38^{\mathrm{b}}$ & $2,97^{\mathrm{bc}}$ & $2,54^{\mathrm{a}}$ & $2,82^{\mathrm{a}}$ \\
\hline & 5 & $2,13^{\mathrm{a}}$ & $3,85^{\mathrm{c}}$ & $2,49^{\mathrm{a}}$ & $2,77 \mathrm{de}$ & $2,13^{\mathrm{a}}$ & $3,85^{\mathrm{c}}$ & $2,49^{\mathrm{a}}$ & $3,31^{\mathrm{c}}$ & $3,28^{\mathrm{b}}$ \\
\hline \multirow[t]{2}{*}{20} & 2,5 & $4,05^{\mathrm{c}}$ & $3,38^{\mathrm{b}}$ & $3,13^{\mathrm{c}}$ & $1,97^{\mathrm{a}}$ & $4,05^{\mathrm{c}}$ & $3,38^{\mathrm{b}}$ & $3,13^{\mathrm{c}}$ & $2,82^{\mathrm{ab}}$ & $3,05^{\mathrm{ab}}$ \\
\hline & 5 & $4,13^{\mathrm{c}}$ & $2,92^{\mathrm{a}}$ & $2,46^{\mathrm{a}}$ & $2,95^{\mathrm{e}}$ & $4,13^{\mathrm{c}}$ & $2,92^{\mathrm{a}}$ & $2,46^{\mathrm{a}}$ & $3,69^{\mathrm{d}}$ & $3,85^{\mathrm{c}}$ \\
\hline
\end{tabular}

Keterangan : Notasi yang sama menunjukkan tidak beda nyata menurut uji Mann Whitney $\alpha=0,05$

Perbedaan warna pada yoghurt akibat perbedaan penambahan sari buah apel dan madu yang berbeda di setiap perlakuan. Warna sari buah ape adalahl kuning keruh dan agak coklat sedangkan warna madu adalah coklat kekuningan. Oleh karena itu warna yogurt yang dihasilkan dari bahan tersebut adalah berkisar antara kuning hingga coklat. Semakin tinggi persentase penambahan sari buah apel dan madu, maka warna yoghurt akan semakin coklat. Sari buah apel rome beauty berwarna kuning keruh dan agak coklat. Warna coklat pada sari buah apel rome beauty disebabkan adanya proses pencoklatan (browning). Pencoklatan (browning) timbul karena reaksi enzimatis dan muncul setelah buah dipotong. Madu yang digunakan berwarna coklat kekuningan. Warna coklat kekuningan merupakan warna alami dari madu, warna tersebut dihasilkan dari pigmen warna madu yaitu antosianin. Menurut (Anggraini \& Radiati, 2016), pada minuman madu sari apel mengandung enzim polifenol oksidase dari buah apel. Enzim menyebabkan reaksi pencoklatan enzimatis yang menghasilkan warna cokelat (melamin). Reaksi enzimatis ini 
dapat dicegah dengan perlakuan blansing menggunakan suhu tinggi.

Rasa asam dan aroma pada yoghurt dihasilkan dari aktivitas bakteri asam laktat (BAL) yaitu Lactobacillus bulgaricus dan Streptococcus thermophillus yang berperan sebagai starter pada proses fermentasi. Bakteri tersebut memiliki kemampuan untuk menurunkan $\mathrm{pH}$ dan merubah laktosa yang terkandung dalam susu menjadi asam laktat yang berasa asam. Selain mampu menurunkun $\mathrm{pH}$, aktivitas BAL ini juga mampu mengasilkan aroma khas yoghurt (Rosiana, 2016). Bakteri asam laktat (BAL) sebagai starter pada proses fermentasi berpengaruh terhadap pembentukan tekstur pada yoghurt. Bakteri tersebut akan mengubah laktosa yang berasal dari susu sapi menjadi glukosa dan galaktosa, selanjutnya jenis monosakarida ini akan masuk ke jalur glikolisis membentuk asam piruvat. Selanjutnya asam piruvat akan diubah menjadi produk akhir yaitu asam laktat. Asam laktat inilah yang membuat $\mathrm{pH}$ yoghurt menjadi asam. Perubahan derajat keasaman $(\mathrm{pH})$ mempengaruhi protein dari susu sapi yang berupa kasein. Pada titik isoelektrik $(\mathrm{pH} \mathrm{4,6)}$ atau lebih rendah, kasein menjadi tidak stabil sehingga protein akan menggumpal (terkoagulasi). Gumpalan ini akan membentuk struktur yoghurt yang semisolid dan kental.

\section{Syarat Mutu Yoghurt}

Perlakuan terbaik diuji berdasarkan rangking kesukaan. Panelist diminta mengurutkan kesukaan yogurt mulai dari yang paling disukai sampai paling tidak disukai. Yogurt dengan rangking tertinggi merupakan perlakuan terbaik. Berdasarkan Tabel 4 dapat diketahui bahwa perlakuan terbaik yaitu pada perlakuan $20 \%$ sari buah apel dan 5\% madu.

Yogurt perlakuan terbaik kemudian dibandingkan dengan SNI 2981: 2009 tentang syarat mutu yogurt. Pada Tabel 5 menunjukkan bahwa yogurt hasil penelitian telah sesuai dengan syarat mutu SNI yogurt kecuali dari segi penampakan atau tekstur. Yogurt hasil penelitian memiliki penampakan yang cair, sedangkan pada SNI yogurt harus memiliki penampakan cair-kental dan padat. Hal ini disebabkan oleh penggunaan sari apel yang lebih tinggi sehingga meningkatkan jumlah air. Panelis agak menyukai yogurt yang terbuat dari sari buah apel dan madu.

Tabel 4. Hasil Uji Rangking Yoghurt

\begin{tabular}{ccc}
\hline Sari Buah Apel (\%) & Madu (\%) & Rangking \\
\hline 10 & 2,5 & $4,03^{\text {cd }}$ \\
& 5 & $3,44^{\mathrm{c}}$ \\
15 & 2,5 & $4,69^{\mathrm{d}}$ \\
& 5 & $2,69^{\mathrm{b}}$ \\
& 2,5 & $4,18^{\mathrm{d}}$ \\
& 5 & $1,97^{\mathrm{a} *}$ \\
\hline
\end{tabular}

*perlakuan terbaik

\section{Takaran Saji}

Terdapat 8 jenis diet pada diabetes mellitus mulai dari diet 1100 kkal hingga 2500 kkal. Kebutuhan kalori untuk makanan selingan yaitu 20-30\% dari total energi harian, yaitu berkisar antara 11-37,5 kkal. Konsumsi yogurt sebanyak 20-45 $\mathrm{g} /$ porsi sajian/hari dapat memenuhi kebutuhan makanan selingan tersebut. Kalori yang disumbang dari yogurt ini adalah sebanyak 15,6-35,1 kkal dengan kadar gula sebanyak $0,9-2,1 \%$. Asupan gula ini masih tergolong lebih rendah dari batas asupan gula untuk diet diabetes yaitu $5 \%$ (Tabel 6). 
Tabel 5. Karakteristik Yoghurt Perlakuan Terbaik Dibandingkan dengan SNI 2981 : 2009

\begin{tabular}{lcll}
\hline \multicolumn{1}{c}{ Karakteristik } & Satuan & \multicolumn{1}{c}{$\begin{array}{c}\text { Yogurt Hasil } \\
\text { Penelitian }\end{array}$} & \multicolumn{1}{c}{ SNI Yogurt } \\
\hline Keadaan & - & Cair (agak suka) & $\begin{array}{l}\text { Cairan-kental- } \\
\text { penampakan/tekstur }\end{array}$ \\
Bau/aroma & - & $\begin{array}{l}\text { Normas khas yogurt } \\
\text { (agak suka) }\end{array}$ & Normal/khas \\
Rasa & - & Hambar (agak suka) & Asam/khas \\
Konsistensi & - & homogen & homogen \\
Warna & - & Coklat kekuningan & - \\
& & (agak suka) & Min 2,7 \\
Protein & $(\%)$ & 3,45 & Maks 3,8 \\
Lemak & $(\%)$ & 2,29 & - \\
Karbohidrat & $(\%)$ & 5,23 & - \\
Energi & Kkal & 54,95 & - \\
Kadar air & $(\%)$ & 88,46 & - \\
Kadar abu & $(\%)$ & 0,66 & Min $10^{7}$ \\
pH & - & 4,5 & $0,5-2,0$ \\
Total bakteri asam laktat & Koloni/g & $8,3 \times 10^{8}$ & - \\
Keasaman & $(\%)$ & 1,91 & - \\
Aktivitas antioksidan & $(\%)$ & 32,83 & 4,69 \\
Kadar gula total & $(\%)$ & & \\
\hline
\end{tabular}

Tabel 6. Porsi Sajian Yogurt yang Disarankan untuk Berbagai Jenis Diet Diabetes Mellitus

\begin{tabular}{|c|c|c|c|c|c|c|}
\hline \multirow{2}{*}{$\begin{array}{c}\text { Jenis } \\
\text { Diet } \\
\text { (kkal) }\end{array}$} & \multirow{2}{*}{$\begin{array}{c}\text { Kebutuhan } \\
\text { Kalori untuk } \\
\text { Selingan (20- } \\
30 \%) \text { (kkal) }\end{array}$} & \multicolumn{2}{|c|}{ Porsi Sajian } & \multirow{2}{*}{$\begin{array}{c}\text { Kadar } \\
\text { Gula Total } \\
\text { Yogurt } \\
(\mathrm{g} / 100 \mathrm{~g})\end{array}$} & \multirow{2}{*}{$\begin{array}{c}\text { Kalori dari } \\
\text { Gula Total } \\
\text { Yogurt } \\
(\text { kkal) }\end{array}$} & \multirow{2}{*}{$\begin{array}{l}\text { Kalori } \\
\text { Total } \\
\text { Yogurt } \\
\text { (kkal) }\end{array}$} \\
\hline & & Berat (g) & Kali/hari & & & \\
\hline 1100 & $11-16,5$ & 20 & $2 \mathrm{x}$ & 0,9 & 11 & 15,6 \\
\hline 1300 & $13-19,5$ & 23 & $2 \mathrm{x}$ & 1,1 & 12,6 & 17,9 \\
\hline 1500 & $15-22,5$ & 27 & $2 \mathrm{x}$ & 1,3 & 14,8 & 21,0 \\
\hline 1700 & $17-25,5$ & 31 & $2 \mathrm{x}$ & 1,5 & 17,0 & 24,2 \\
\hline 1900 & $19-28,5$ & 34 & $2 \mathrm{x}$ & 1,6 & 18,7 & 26,5 \\
\hline 2100 & $21-31,5$ & 38 & $2 \mathrm{x}$ & 1,8 & 20,9 & 29,6 \\
\hline 2300 & $23-34,5$ & 41 & $2 \mathrm{x}$ & 1,9 & 22,5 & 31,9 \\
\hline 2500 & $25-37,5$ & 45 & $2 \mathrm{x}$ & 2,1 & 24,7 & 35,1 \\
\hline
\end{tabular}

Secara umum yoghurt ini dapat digunakan sebagai makanan selingan dengan memenuhi kebutuhan kalori dari gula sederhana yang diperbolehkan untuk dikonsumsi bagi pasien diabetes melitus. Sedangkan untuk aktivitas antioksidan pada produk terbaik adalah $32,83 \%$ (sedang) yang artinya yoghurt mempunyai $32,83 \%$ peredaman terhadap radikal bebas DPPH. Menurut Setyabudi dkk. (2015) aktivitas antioksidan sebesar $34,2 \%$ pada ekstrak jeruk purut dengan metode maserasi yang menggunakan pelarut etanol mampu berfungsi menjadi antidiabetes.

\section{KESIMPULAN}

Aktivitas antioksidan pada yoghurt dengan penambahan sari buah apel dan madu adalah $27,10 \%$ sampai $32,83 \%$, sedangkan untuk kadar gula total 2,53$4,69 \%$. Penambahan sari buah apel dan madu dengan berbagai konsentrasi pada yoghurt berpengaruh nyata terhadap mutu 
hedonic dan kesukaan (hedonic), kecuali aroma. Perlakuan terbaik yaitu perlakuan A3B2 yakni dengan konsentrasi penambahan sari buah apel rome beauty $20 \%$ dan madu $5 \%$ yang sesuai standar SNI 2891-2009.

Perlakuan terbaik diperoleh dari penggunaan ekstrak apel $20 \%$ dan 5\% madu yaitu memiliki aktivitas antioksidan $32,83 \%$ (sedang), kadar gula total $4,69 \%$ (rendah), rasa yang hambar, warna coklat kekuningan, aroma khas yoghurt kuat, dan tekstur yang cair. Yogurt ini agak disukai dari warna, rasa, aroma, dan tekstur. Yoghurt ini memiliki kandungan lemak $2,29 \%$, protein $3,45 \%$, karbohidrat $5,13 \%$, kadar air $88,46 \%$, kadar abu $0,66 \%$, energi 54,95 kkal, $\mathrm{pH} 4,5$, total bakteri asam laktat $8,3 \times 10^{8} \mathrm{koloni} / \mathrm{g}$, dan total asam tertitrasi $1,91 \%$ yang telah sesuai dengan SNI 28912009. Jumlah yogurt yang dikonsumsi sebagai makanan selingan bagi penderita diabetes mellitus adalah berkisar antara 20$45 \mathrm{~g} / \mathrm{hari}$.

\section{DAFTAR PUSTAKA}

Anggraini, D. N., \& Radiati, L. E. (2016). Penambahan carboxymethyle cellulose ( $\mathrm{cmc}$ ) pada minuman madu sari apel ditinjau dari rasa , aroma , carboxymethyle cellulose ( cmc ) addition in term of taste , aroma , color , $\mathrm{pH}$, viscosity , and turbidity of apple cider honey drink. Jurnal Ilmu \& Teknologi Hasil Ternak, 11(1), 59-68.

Butsat, S., \& Siriamornpun, S. (2016). Effect of solvent types and extraction times on phenolic and flavonoid contents and antioxidant activity in leaf extracts of Amomum chinense C. International Food Research Journal, 23(1), 180-187.

Dalimartha, S. dan F. A. (2013). Fakta Ilmiah Buah Sayur. Jakarta: Penebar Plus.
Dinas Kesehatan Kabupaten Jember. (2016). Data Diabetes Melitus Kabupaten Jember. Jember: Dinas Kesehatan Kabupaten Jember.

Ejtahed, H. S., Mohtadi-Nia, J., Homayouni-Rad, A., Niafar, M., Asghari-Jafarabadi, M., \& Mofid, V. (2012). Probiotic yogurt improves antioxidant status in type 2 diabetic patients. Nutrition, 28(5), 539-543. https://doi.org/10.1016/j.nut.2011.08.013

Hastuti, A. dan N. R. (2014). Pengaruh Penambahan Kayu Manis terhadab Aktivitas Antioksidan dan Kadar Gula Total Minuman Fungsional Secang dan Daun Stevia Sebagai Alternatif Minuman Bagi Penderita Diabetes Melitus Tipe 2. Journal of Nutrition College, 3(4), 362-369.

Kementerian Kesehatan Republik Indonesia. (2013). Riset Kesehatan Dasar. Jakarta: Badan Penelitian dan Pengembangan Kesehatan Kementerian Kesehatan Republik Indonesia.

Khotimah, L. K. (2016). Perbandingan Efek Pemberian Jus Buah Apel Hijau (Mallus sylvestris Mill.) dan Jus Buah Apel Merah (Mallus domestica Borkh.) terhadap Gangguan Toleransi Glukosa Darah pada Tikus Putih Jantan Akibat Efek Samping Deksametason. Sekolah Tinggi Ilmu Kesehatan Ngudi Waluyo Ungaran, Ungaran.

Kinanthi, D. (2016). Pengaruh Penambahan Sari Buah Apel terhadap Nilai pH dan Jumlah Bakteri Asam Laktat pada Soyghurt. Universitas Muhammadiyah Surakarta.

Lingga, L. (2012). Bebas Diabetes Tipe-2 Tanpa Obat (1st ed.). Jakarta: PT Agromedia Pustaka. 
Peristiowati, Y. (2016). Monograf: Catechins Green Tea GMB-4 Sebagai Antidiabetik. Yogyakarta: Indomedia Pustaka.

Rosiana, N. M., \& Amareta, D. I. (2016). Karakteristik Yogurt Edamame Hasil Fermentasi Kultur Campuran Bakteri Asam Laktat Komersial Sebagai Pangan Fungsional Berbasis BijiBijian (pp. 33-37). Jember.

Setiawan, B., \& Suhartono, E. (2005). Stres Oksidatif dan Peran Antioksidan pada Diabetes Melitus. Majalah Kedokteran Indonesia, 55, 86-91.
Subakti, Y. dan D. R. A. (2012). Bahan Makanan Terbaik Menurut AlQur'an dan Sunnah. (1st ed.). Yogyakarta: Pustaka Albana.

Umami, C. (2015). Pengaruh Penambahan Ekstrak Kayu Secang dan Ekstrak Daun Stevia terhadap Aktivitas Antioksidan dan Kadar Gula Total pada Yoghurt sebagai Alternatif Minuman Bagi Penderita Diabetes Melitus Tipe 2. Universitas Diponegoro Semarang.

Uttuh, A. A. (2016). Penambahan Sari Buah Duwet (Syzygium cumini) terhadap Aktivitas Antioksidan Yoghurt. Politeknik Negeri Jember. 